\title{
(Re)discovering the Familial Past and Its Impact on Historical Consciousness
}

\author{
Emma L. Shaw * and Debra J. Donnelly
}

check for updates

Citation: Shaw, Emma L., and Debra J. Donnelly. 2021. (Re)discovering the Familial Past and Its Impact on Historical Consciousness. Genealogy 5: 102. https://doi.org/10.3390/ genealogy5040102

Received: 25 October 2021

Accepted: 25 November 2021

Published: 1 December 2021

Publisher's Note: MDPI stays neutral with regard to jurisdictional claims in published maps and institutional affiliations.

Copyright: (c) 2021 by the authors. Licensee MDPI, Basel, Switzerland. This article is an open access article distributed under the terms and conditions of the Creative Commons Attribution (CC BY) license (https:/ / creativecommons.org/licenses/by/ $4.0 /)$.
School of Education, College of Human \& Social Futures, The University of Newcastle, Callaghan, NSW 2308, Australia; Debra.donnelly@newcastle.edu.au

* Correspondence: emma.shaw@newcastle.edu.au

\begin{abstract}
Family history has become a significant contributor to public and social histories exploring and (re)discovering the micro narratives of the past. Due to the growing democratisation of digital access to documents and the proliferation of family history media platforms, family history is now challenging traditional custodianship of the past. Family history research has moved beyond the realms of archives, libraries and community-based history societies to occupy an important space in the public domain. This paper reports on some of the findings of a recent study into the historical thinking and research practices of Australian family historians. Using a case study methodology, it examines the proposition that researching family history has major impacts on historical understanding and consciousness using the analytic frameworks of Jorn Rüsen's Disciplinary Matrix and his Typology of Historical Consciousness. This research not only proposes these major impacts but argues that some family historians are shifting the historical landscape through the dissemination of their research for public consumption beyond traditional family history audiences.
\end{abstract}

Keywords: historical consciousness; family history research; family historians; temporal orientation; case study

\section{Introduction}

Family history research is rapidly changing, and influencing, the historical landscape. This multi-billion-dollar industry sees millions of people around the world researching and (re)discovering their familial pasts. Revolutionised by technological advances, family history research has moved beyond the realms of archives, libraries and community-based history societies to occupy an important space in the public domain. Today we see family history represented across multiple media platforms intended for popular consumption such as investigative television, docudramas, advertising spaces, and DNA testing sites to name a few (Donnelly and Shaw 2020). Coupled with the proliferation of websites and databases, in addition to how-to books, magazines, and thousands of social media groups and family history societies worldwide, family history research has become a global phenomenon.

Consequentially, family histories have become an important contributor to public and social histories exploring and publicising the micro narratives of the past. Burgeoned by widely available historical information, and a growing democratisation of digital access to documents, the family history 'boom' represents an historiographic shift in the perceived custodianship of the past. Family historians, once considered to be the 'poor cousins' of academic historians, are now widely consulted by those in the academy in the (re)creation of local, social, public and other histories (Evans 2021). While family historians are often self-taught, many are able to draw on historical research methodologies, and are skilled and flexible in locating, corroborating, and contextualising a vast array of sources in the compilation of their familial narratives (Kramer 2011; Evans 2021; Shaw 2020). Such narratives shift between the familial and the broader historical sphere, as the past is reformed and retold, and thus present a diverse range of alternative historical perspectives. 
This paper reports on some of the findings of a recent study into the historical thinking and research practices of Australian family historians. Using a case study methodology, we examine the proposition that some family historians are mirroring the work of academic historians and developing advanced historical consciousness by considering their disciplinary practices and understandings through an analytic alignment with Jorn Rüsen's Disciplinary Matrix (Rüsen 1993) and his Typology of Historical Consciousness (Rüsen 1996). Rüsen is a well-known as a philosopher of history and is particularly interested in the role of history in intersection between the past and present. His disciplinary matrix, examines the part played by issues of motives, functions, theories, representations, and methods, and allows for the investigation of both the ontological and practical aspects of family history research. Applying this matrix and the typology to the selected case studies is an important way to see how family history research impacts on an individual's relationship to, and understandings of, the past which is commonly referred to as an historical consciousness.

\section{Conceptualising Historical Consciousness}

Since the 1970s, much scholarly interest has focussed on the formation of historical consciousness and the ways that researchers construct narratives to understand themselves as historical beings, orientated in place and time (Seixas 2006). The influential German philosopher Hans-Georg Gadamer (1977) characterises historical consciousness as a cultural manifestation with a specific locality in space and time, claiming "historical consciousness no longer listens sanctimoniously to the voice that reaches out from the past but, in reflection on it, replaces it within the context where it took root in order to see the significance and relative value proper to it" (p. 9). More recently, Swedish academic Robert Thorpe (2014) explained, "at the most fundamental level a historical consciousness is manifested through narratives, and these narratives can be applied to uses of history on an individual level and historical culture on a societal or public level" (p. 19). This aligns with Rüsen's (2004) views of historical consciousness "as a synthesis of moral and temporal consciousness" (p. 78) arguing our reactions to any given situation depends on our socially constructed sense of morality, and what we know contextually and historically about a situation. Rüsen views our historical consciousness as "a necessary prerequisite" to navigate the present and to plan for the future (p. 66).

In his work on historical consciousness, Rüsen $(1996,2006)$ developed a typology, which identified and outlined four types of historical consciousness: traditional; exemplary; critical; and genetic historical consciousness. He argued that the principals of 'tradition' is grounded in meaning and sense-making which remain the most popular and the most frequently used and provide a "cultural orientation for practical human life using certain reference to the past" (p. 46). He further insists that tradition is "the starting point for every development of historical consciousness" (p. 50). Exemplary historical consciousness uses events in the past to provide general rules that can be applied to similar cases in the present. Critical historical consciousness is more sophisticated in that the individual understands that much truth in history is reliant on point of view, yet do not view themselves as historical beings. The final stage of the Typology Rüsen calls Genetic historical consciousness. Here, the individual understands how knowledge is a construction that changes over time and that historical evidence requires contextualisation. As Thorpe (2014) argues, "an individual that has no understanding of the contextual contingency of history cannot make a genetic use of history". (p. 21). Peter Seixas (2006) used Rüsen's Typology as a heuristic to further explore the discipline of history. A synopsis is presented in Table 1 below. 
Table 1. Epistemic qualities of historical consciousness (adapted from Seixas 2006, pp. 145-49).

\begin{tabular}{|c|c|}
\hline $\begin{array}{c}\text { Types of Historical } \\
\text { Consciousness }\end{array}$ & Understanding History \\
\hline Traditional & $\begin{array}{l}\text { - Epistemologically rudimentary } \\
\text { - No means for a critical assessment of history or historical } \\
\text { accounts } \\
\text { - No means for treating contradictory accounts of history }\end{array}$ \\
\hline Exemplary & $\begin{array}{l}\text { - Turns history into a positivist science } \\
\text { - Values (such as 'human rights') are historically derivative } \\
\text { - Treats historical account as substantive, yet engages with how to } \\
\text { verify or falsify historical claims }\end{array}$ \\
\hline Critical & $\begin{array}{l}\text { - Questions the possibility of truth in history } \\
\text { - Does not offer a method of how to treat history, apart from } \\
\text { falsifying or verifying its accounts } \\
\text { - } \quad \text { Displays an inability to historicise the point of the researcher }\end{array}$ \\
\hline Genetic & $\begin{array}{l}\text { Displays an appreciation that knowledge is constructed by a } \\
\text { community of inquiry } \\
\text { - Historical knowledge changes over time and must be } \\
\text { contextually bound to the historical era in which it was created } \\
\text { - False and true historical accounts are treated with complexity }\end{array}$ \\
\hline
\end{tabular}

Therefore, historical consciousness is more than how we think about the past. It is linked to personal and cultural identity and is influenced by "all things historical" (Rüsen 2004, p. viii). An individual's historical consciousness is potentially influenced and enhanced by engaging in historical research activities such as investigating one's family history or undertaking study of history in a formal institution of learning, both of which involve the creation of historical outputs, such as essays, books, and family trees. These historical understandings often spill into interests and pastimes, such as reading historical novels, watching with historical films and documentaries, attending museums, watching historically themed television programmes, travelling to places of historical significance. Rüsen's Disciplinary Matrix links disciplinary knowledge and history in everyday life, while his typology serves to describe various types of historical consciousness. Lee (2004) makes the important point that the Typology is not a "ladder-like progression" (p. 5) with each stage building on the former, but that the stages can co-exist and change depending on the individuals' encounter with the past.

\section{Research Design and Case Study as a Methodology}

This research reports on part of the findings of a larger qualitiative study investigating the research practices and historical thinking and consciousness of Australian family historians (Shaw 2020). Qualitative research involves collecting an analysing non-numerical data through an analysis of investigative methods such as interviews, observations, and openresponse survey questions (Creswell 2012). It focuses on gaining insight an understanding of an individual's perceptions and understandings of their lived experience. The study used a tri-phase design comprised of survey $(n=1406)$, semi-structured interviews $(n=11)$ and the development of four in-depth case studies. The triangulated case study data were aligned to Rüsen's Disciplinary Matrix and the case studies' historical consciousness were framed against the Typology of Historical Consciousness to explore their practical and theoretical workings as historians, which form the focus of this paper.

Qualitative case study design is appropriate for this paper as it allows the researchers to draw from the wisdom and insight of those who have experienced family history research and understand its impact on perceptions of the present. "One selects a case study approach because one wishes to understand the particular in depth" (Merriam 1998, p. 173). Case studies are examples of purposeful sampling and present an in-depth study of 
exemplary "information-rich cases" (Sandelowski 1995, p. 180). Case study, as a research methodology, is commonly defined as "an in-depth exploration of a bounded system (activity, event, process, or individuals) based on extensive data collection" (Creswell 2012, p. 465; Stake 1995). A bounded system means that the case is separated out for research in terms of time, place or some physical boundaries (Creswell 2012). The case studies in this project were bounded in time being examples of family historians in the early 21st century and by location all living and working in Australia. They are all examples of single case designs which are used to confirm or challenge a theory, or to represent a unique or extreme case (Yin 1989).

Yin (1989) defines case study is "an empirical inquiry ... when the boundaries between phenomenon and context are not clearly evident; and in which multiple sources of evidence are used" (p. 23). Single-case designs require careful investigation to avoid misrepresentation and to maximise the investigator's access to the evidence. Each individual case study consists of a "whole" study, in which facts are gathered from various sources and conclusions drawn on those facts (Tellis 1997), and are not selected for the purposes of generalisability (Lincoln and Guba 2000; Stake 1995). "It [a case study] provides a slice from the lifeworld that is the proper subject matter for the interpretivist inquirer ... every topic must be seen as carrying its own logic, sense and order, structure and meaning" (Denzin 2005, pp. 133-34).

These case studies exemplify distinctive approaches to family history investigation. The voices of the family history researchers are a vital element in these case studies, and direct quotations from the data are a feature of the reported findings. The voices of the participants in the cases are added to that of the researchers, so providing the reader with a more vivid and nuanced account (Tellis 1997). By adopting this approach, the researchers were able to share the practitioner experience and learn about their family history investigative practices and its impact on their sense of the past and the impact of this on their lives.

The case study subjects were volunteers selected from the interviewees. Their survey and interview responses were used as a means of identifying accomplished researchers, with diverse interests and outputs. All indicated a strong interest in history more broadly, but the motives for commencing their familial research varied markedly. The case study subjects reflected the gender imbalance and ethnic homogeneity of the survey respondents. Three case study subjects identified as female, and one identified as a male. All identified as Anglo-Celtic, but were diverse in that they represented different demographics in age, location, research experience, and hours dedicated to familial research. They had studied at the tertiary level, and except Jane, had studied disciplinary history at high school. Jane was formally trained in historical research methodologies, and the others were self-taught family history researchers. All the case study subjects shared their discoveries with family and John, Jane, and Claire were published authors. A synopsis of the case study subjects is presented in Table 2 below.

Table 2. Demographic overview of case study participants.

\begin{tabular}{|c|c|c|c|c|c|c|c|c|c|}
\hline & Gender & Age & $\begin{array}{l}\text { Highest Level of } \\
\text { Education }\end{array}$ & Profession & $\begin{array}{l}\text { Level of } \\
\text { History } \\
\text { Studies }\end{array}$ & $\begin{array}{c}\text { Year FH Was } \\
\text { Started }\end{array}$ & $\begin{array}{l}\text { Hours per } \\
\text { Week }\end{array}$ & $\begin{array}{c}\text { Membership } \\
\text { of Historical } \\
\text { Society }\end{array}$ & $\begin{array}{c}\text { Publication } \\
\text { of } \\
\text { Findings }\end{array}$ \\
\hline John & male & 46 & Bachelor degree & HR consultant & - school & $1980 s+2013$ & $1-40+$ & yes & yes \\
\hline Jane & female & 41 & $\begin{array}{l}\text { Postgraduate } \\
\text { coursework }\end{array}$ & $\begin{array}{l}\text { Educational } \\
\text { administrator }\end{array}$ & $\begin{array}{l}\text { - school } \\
\text { - university }\end{array}$ & 2000 & 20 & yes & yes \\
\hline Lucy & female & 25 & $\begin{array}{l}\text { Postgraduate } \\
\text { coursework }\end{array}$ & Lawyer & - school & 2005 & 5 & no & no \\
\hline Claire & female & 69 & $\begin{array}{l}\text { Postgraduate } \\
\text { coursework }\end{array}$ & Science teacher & - school & 1984 & $20+$ & yes & yes \\
\hline
\end{tabular}




\section{Rüsen's Disciplinary Matrix as an Analytical Tool}

Rüsen (1993) developed a Disciplinary Matrix which embraces five central factors or principles of historical thinking: the cognitive interest of human beings in having an orientation in time; theories or "leading views" concerning the experiences of the past; empirical research methods; forms of representation; and the function of offering orientation to society (Megill 1994). Within the matrix, Theories (conceptions of history), Methods (the tools used for empirical work), and Forms of representation (what does the result of the historical inquiry look like) are illustrative of engagement with the history discipline. Interests (societal need for temporal orientation) and Functions (what does the historical inquiry do with regard to identity construction and temporal guidance) relate to 'life practice'.

Rüsen's Disciplinary Matrix (Rüsen 1993) describes the relationship between disciplinary historical knowledge and history in contemporary life, and how these contribute to the development of historical consciousness. The Disciplinary Matrix offers a flexible model in which to analyse how individuals interact with the discipline of history and their motivations for doing so. As Gosselin (2012) contends, "the strength of Rüsen's model lies in its ability to recognise the relationship between the internal logic of the historical discipline and everyday life" (p. 59). Chapman (2014) concludes that Rusen's matrix can be useful diagnostically as a tool for identifying dimensions of historical interpretation and he suggests "pedagogies informed by kind of thinking embodied in the matrix can be helpful for progressing historical thinking" and that "Rüsen's model is a valuable tool for organising reflection on historiography and on accounts of historical practice." (p. 70). The matrix is represented diagrammatically in Figure 1 below.

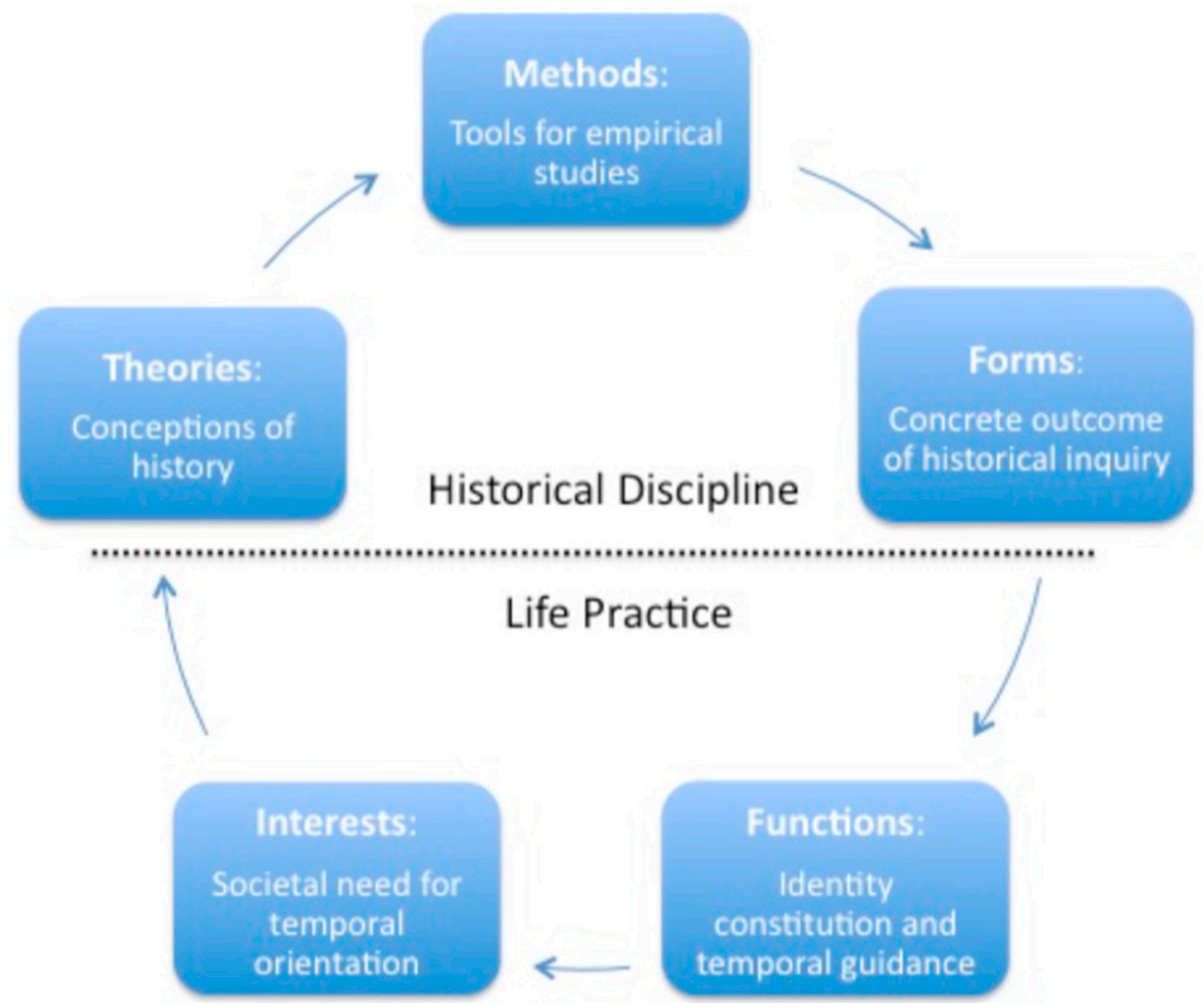

Figure 1. Jorn Rüsen's Disciplinary Matrix (Rüsen 1993).

The case studies in this paper were examined in alignment with the central factors of the matrix, and questions were developed to guide the analytic process as outlined in Table 3 below. Rüsen's matrix has been modified and individualised for each of the four case studies to determine the impact of family history research and its relationship to 
historical consciousness. These adapted diagrammatical representations, presented as Figures $2-5$, facilitate comparing and contrasting of the case studies.

Table 3. Guiding analytic questions in alignment with the Disciplinary Matrix.

\begin{tabular}{ll}
\hline \multicolumn{1}{c}{ Rüsen's Disciplinary Matrix } & \multicolumn{1}{c}{ Guiding Analytic Questions } \\
\hline 1. Interest in orientation in time. & $\begin{array}{l}\text { What is the family history researchers interested in } \\
\text { (re)discovering? What are the motivations? }\end{array}$ \\
\hline 2. Theories or conceptions of history: & $\begin{array}{l}\text { How does the family history researcher define history? } \\
\text { What does it mean to interpret the past? }\end{array}$ \\
\hline $\begin{array}{l}\text { 3. Tools and methodologies used for } \\
\text { empirical work }\end{array}$ & $\begin{array}{l}\text { How does the family history researcher explore } \\
\text { emergent questions and themes about the past? }\end{array}$ \\
\hline 4. Forms of historical representation & $\begin{array}{l}\text { In what ways does the family history researcher } \\
\text { convey their historical argument and/or discoveries. } \\
\text { What are the main ideas coming from the research? }\end{array}$ \\
\hline $\begin{array}{l}\text { 5. Function of identity construction and } \\
\text { temporal guidance. }\end{array}$ & $\begin{array}{l}\text { What impacts do these new discoveries and } \\
\text { understandings of the familial past have in terms of } \\
\text { identity formation and temporal guidance? }\end{array}$ \\
\hline
\end{tabular}

- Case study 1: John (pseudonym), 46 Year-old HR consultant.

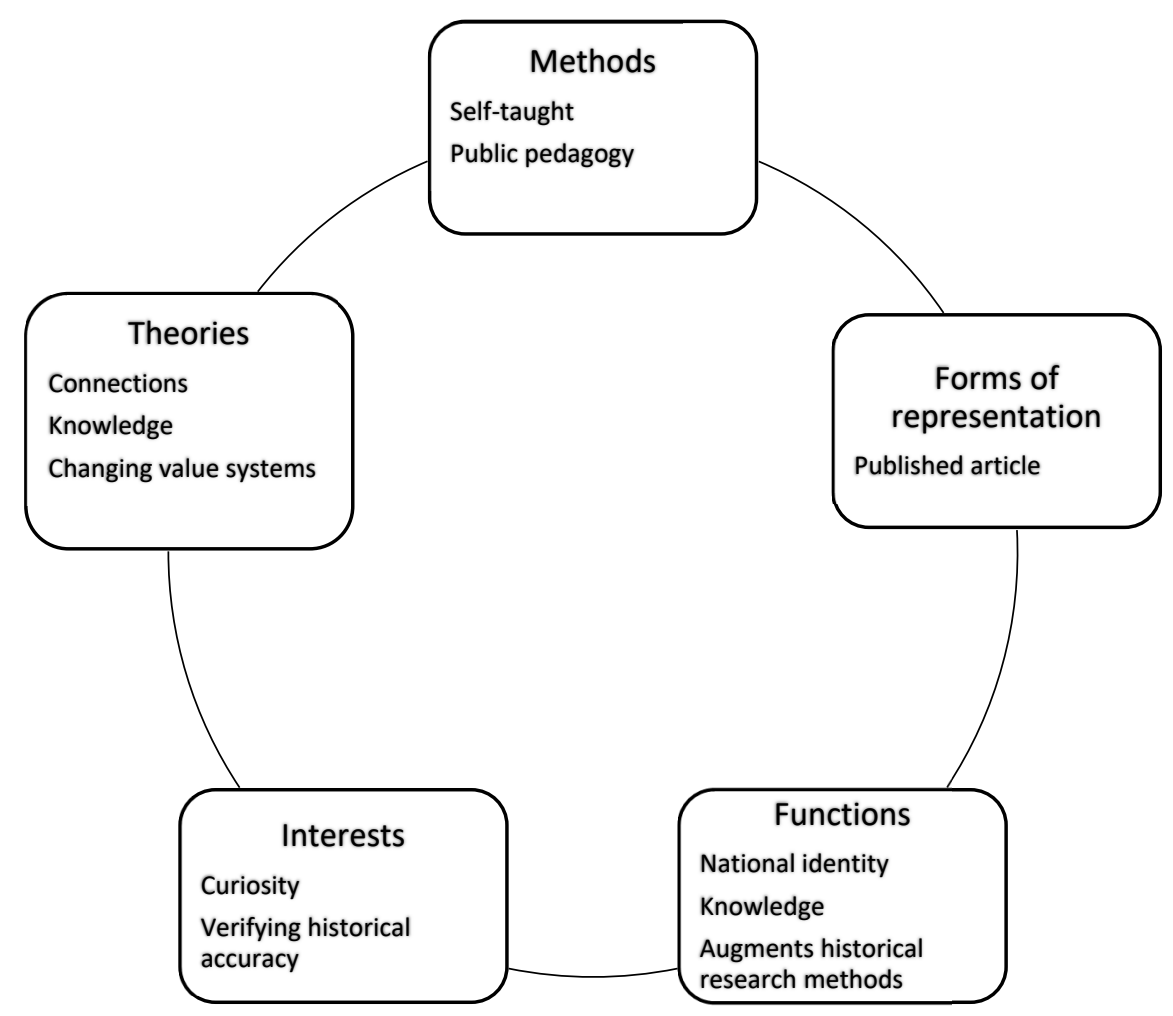

Figure 2. Case study one in alignment with Rüsen's (1993) Disciplinary Matrix.

John lives in New South Wales, Australia. His highest level of educational attainment is a bachelor's degree, and he had only formally studied history at school. He currently spends up to $40 \mathrm{~h}$ per week researching his family history and is a member of a historical society. John commenced his family history research in 1979 citing "simple interest" but explained that "you didn't know what was available ... it was like staring into a big black hole, not knowing what to look for or what was available, or how to go about it". He recommenced his research in 2013 when he uncovered a family connection to a famous 
Australian artwork, and through his research, was able to challenge the written history of a painting of national significance. He tells that

Back when I first started in 1979, I initially spoke to my mother [about the painting]. In addition, it was only 30 years later, when I started to discover and piece together the big puzzle, and I found that ... everything she said, it all fitted in.

John also revealed an interest in acquiring an increase in familial knowledge as he reported "I needed to understand not just how, not just the story of [name] in it, and what came before him, and also what came after him, to understand what happened with the land. And I also wanted to know how he acquired land". This meant investigating and eventually correcting an established historical narrative. He spoke of contextualising his research, and explained "It was only by doing that research of not just this narrow, looking down onto [name] but what was around him" that led to a deeper understanding of the past.

John's theory of history was an intense personalisation of the past. Of the painting he said "What I see is my great-uncle. What I see are his cows, and what I see in the background behind him is the shadow of the peppercorn trees the homestead where my great-grandfather was born. And when you start thinking about that, it's, wow. And they lived in this house". Here John illuminates a strong affective connection to this historical artefact. Unlike the other case studies subjects the main thrust of his research is centred on the people around the painting, as opposed to a structured and complete family tree.

John is a self-taught historical researcher but deftly draws upon various methods to develop his family history. In an act of public pedagogy, where learning is seen as "the informal learning and ever educational experiences occurring within popular culture, popular media, and everyday life" (Freishtat and Sandlin 2010, p. 503) he learned to research in and across multiple digital media platforms in addition to informal sites of education such as libraries, archives, museums, and art galleries. John confessed that he felt quite lost when commencing his genealogical journey and increased his skills by trial and error as time progressed. John spoke of using "many, many different guides" and countless websites. He referred to his local library which "has an excellent reference section" and speaking to historians at the archives.

John demonstrated flexibility in his research methods. He "let the painting tell the story" and started by comparing the geographical features of paintings by the same artist and then "looked at parish maps" which led to the use of conveyancing documents and a will. He was able to find out that his ancestor lived in "a two room hut" by exploring probate documents for their estates, which was supported by a "description in the coroner's inquest". Despite being self-taught in historical research, John showed agility in his application of a variety of research apparatuses. He used multiple sources of evidence and recognised the importance of historical context by explaining "I think what it's taught me is that a lot of bad things happened back then. And you've got to realise that the values that we have now, aren't the values that were around at that time. And you then have to start looking at things as to how they looked at things back then".

The form of representation of John's research is a widely distributed article outlining the history of an important Australian painting. There has been previous works written of the painting but as John explained "where are the supporting facts? And there weren't any, it was just someone telling a story". He continued by arguing that he "could've written a document which was literally tearing apart paragraph by paragraph, but that would have just ended up being an article which was us against them ... which wouldn't have proved anything". He has given talks about his research at the National Art Gallery of Australia, and has located and met the descendents of the artist.

John's family history research functioned to strengthen his connection with society, "hard to say how, but I find I can relate more to the history of the country". Another function of his research was that his wider historical knowledge had intensified due to his family history research. His research also functioned to provide him with a deeper appreciation of the present, to understand the past and his historical consciousness was 
augmented by his historical investigations. This aligns with critical historical consciousness of Rüsen's Typology, in that he is interested in exploring the past to verify historical accounts.

- $\quad$ Case study 2: Jane (pseudonym), 41 year-old education administrator

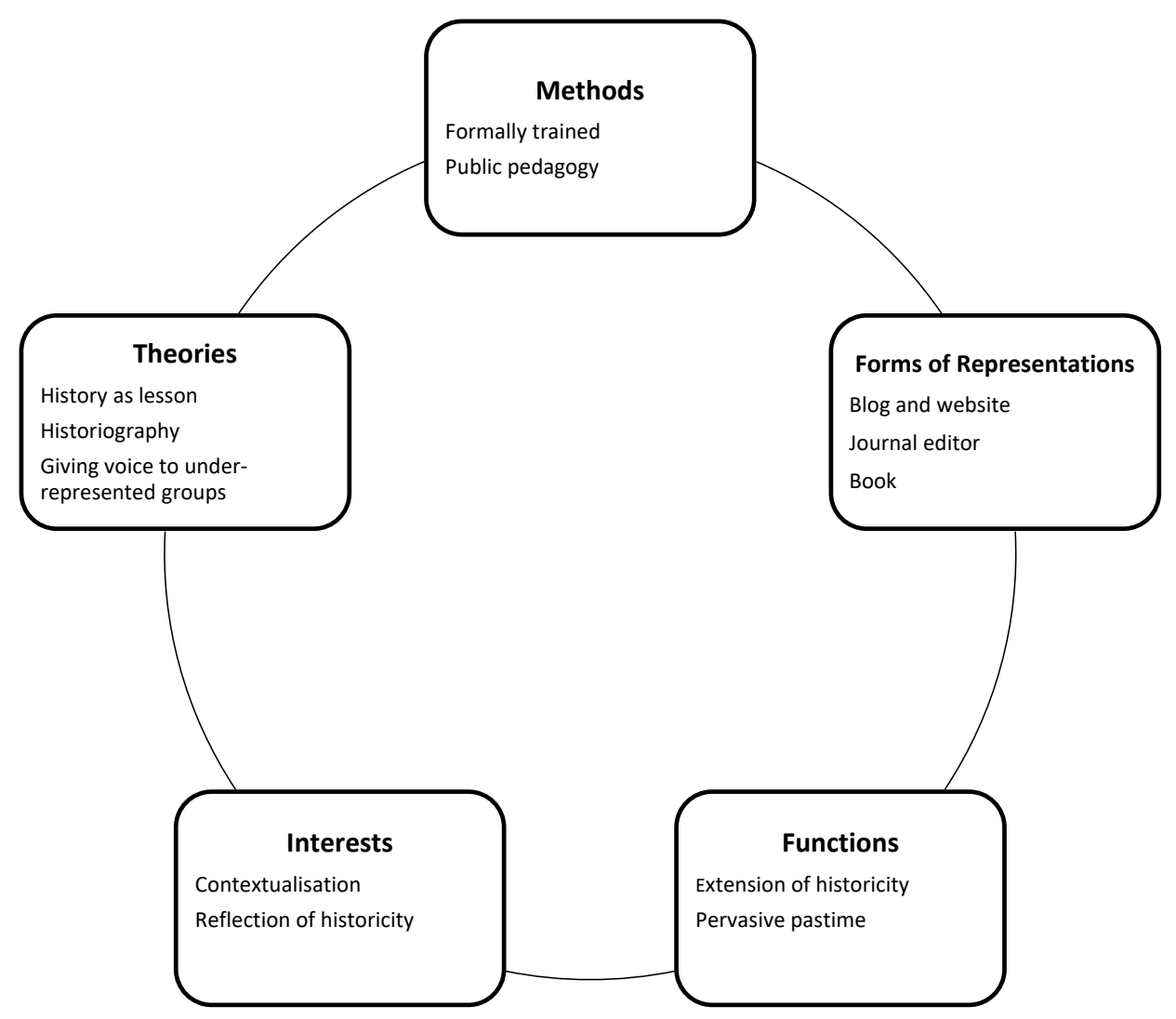

Figure 3. Case study two in alignment with Rüsen's (1993) Disciplinary Matrix.

Jane originally from Victoria, but now resides in New South Wales, Australia. She identifies as Australian with an Anglo-Celtic ethnic cultural background. She is highly educated, having completed a postgraduate coursework degree, and she cites 'education administration' as her occupation. She has been undertaking her family history research for sixteen years and dedicates an average of twenty hours per week to her research. She has studied history as an academic subject at several levels from compulsory history at school to senior history at school and senior extension history at school and then onto university studies with a major in History.

When asked about her theories of history, Jane explained that "It means the study of everything that has contributed to who I am and what the society I live in is and it's something I find very enjoyable to both produce and participate in". For Jane the study of history is about locating herself in time and orientating her life in society. It also meant attention to the disciplinary aspects of historical inquiry, and was a passion to be simultaneously consumed and produced. When asked about her evolving understand of history as a discipline, Jane pointed to a shift from grand in focus to micro-historical narratives within historical scholarship. She acknowledged the recent shift to view history as multi-voiced, with the inclusion of previously marginal historical voices, such as social, women's, indigenous and immigrant histories. Janes successfully locates herself firmly within the contemporary historical climate:

"I think that's just been a natural trend in historical research for the last 40 years anyway, with the rise of indigenous history and religious history and ethnic history, and whatever else, all the people, all the different groups that have been left out of the more 
traditional big picture, important people, dates type history ... It's not so much that the history's changed; it's the way that people look at the history that's changed."

Jane further emphasised the importance of history to contemporary understandings and used a very relevant example, although this interview was held before the COVID Pandemic. She believes that as humans we benefit from learning the lessons of history. As such, Jane saw history as having a didactic purpose and she explains one impact on her historical consciousness from her exploration of history. Jane when searching a parish register for ancestral names when she happened upon a large number of children dying of measles:

[This is an] example of how history impacts on modern life is the anti-vaxers [antivaccinations] people of today. Because anyone that's spent any time doing family history I think would just want to grab these people around the throat and throttle them ... my solution with these people is to drag them to a town of a 19th century cemetery, and make them sit there and read out the gravestone of every kid under the age of five who died of these diseases, and make them do it until they change their mind.

Jane's historical research methods are well developed. Jane is experienced in historical inquiry methodologies acquired through assorted encounters with history as an academic discipline as well as a wide range of learning opportunities focussed on family history research. She cites a wide range a university genealogy course, family history magazines, genealogical television programmes, personal practice, interaction with other family history researchers, participation in online communities, and family history how-to books.

Jane is an established family historian working in various forms of representation. Jane writes a newsletter about family history courses and events, is the editor of the historical society journal, maintains blog and website about family history research methods, and is involved in writing a book in collaboration with the university academics.

Following on from her school and university History studies, Jane has undertaken the role of teacher and mentor to many family and local history researchers. She runs research methodology courses and as such has taken on the role of public pedagogue. Jane is very involved in her historical society being the secretary and journal editor. She is currently working on two projects about World War One soldiers of her local area.

Jane expressed her frustration at the lack of archival organisation within the society, revealing she shouldered the responsibility of attempting to introduce orderliness to the documents and artefacts collected by the society over time.

It's the regular story of most historical societies; it's a very ageing demographic in membership. It's a small society anyway, and it's getting smaller as people basically die, and it's very hard to attract new members.

Jane's leisure activities further highlight her interest in history. She reported that as well as her local historical society work, she undertakes a wide-ranging interest in public history activities such as viewing historical movies and documentaries on television, reading historical non-fiction books, regularly attending museums. She is interested in her family research in its historical context and has a deep understanding of how history influences the present. She sees her family history research as confirmation of her historicity, meaning authenticity based on verifiable evidence.

Jane's historical consciousness has a strong influence on her values, who she is, and how she perceives herself. Her historical activities and practices function as a reflection of her historical ideologies, and she actively produces historical representations and seeks scholarship to support and augment her historical experiences in their totality. Janes' interest in history is all-pervasive as it encompasses, and permeates, all aspects of her life as she claims, "Oh if I win lotto, my life is going to be going from archive to archive ... just jumping into the documents. I could do that for weeks on end, that's not a problem." Jane's historical consciousness is nuanced and sophisticated and with an understanding that time and values systems change over time, placing her at genetic historical consciousness in Rüsen's Typology. 
- Case study 3: Lucy (pseudonym), 25 year-old lawyer

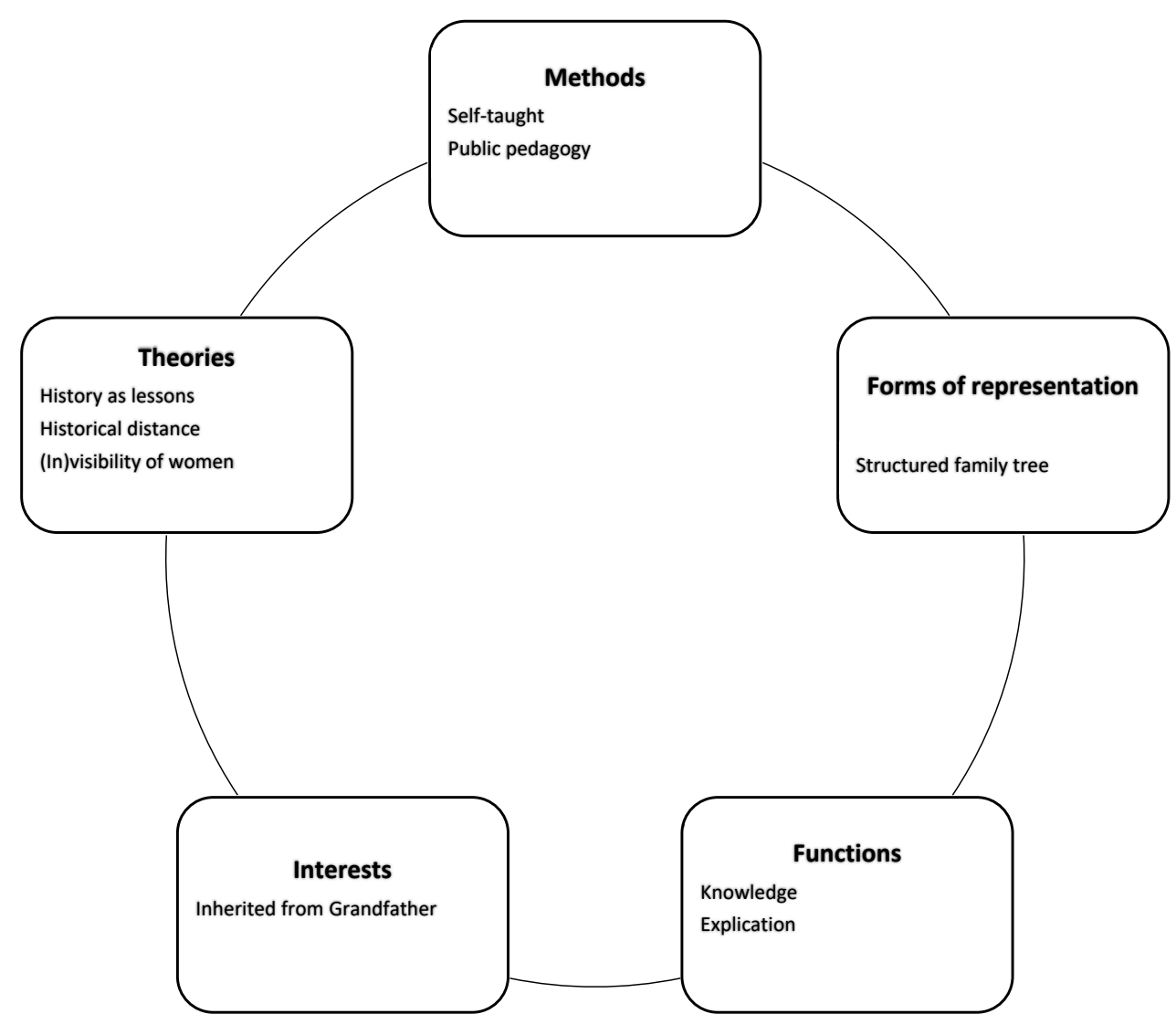

Figure 4. Case study three in alignment with Rüsen's (1993) Disciplinary Matrix.

Lucy is from Sydney, New South Wales. She is currently completing her PhD in law, and she studied history in high school. She commenced her family history research when she was 13 , and she is not a member of a historical society. She has no plans to publish her family history research at this time. Lucy cited her grandfather as the catalyst for her interest in family history research. She explained that he "had started up his family tree and so he would tell us, my brothers and I, some family stories. And he passed on the family tree to me because he thought I might be interested and that's what sort of started it off". As time progressed, her interest became a desire "to get a fuller picture of where my family came from", which culminated in a comprehensive family tree which is the form of representation of her research.

Lucy is also self-taught in historical research methods. She told that "it was really trial and error and Googling ... because I think back when I started there wasn't really a great deal of things online that were freely available as there are now". She spoke of how her research methods grew over time, and of the collegiality of the online genealogical community which "helped out". She told how she cross-referencing her sources, and ensured their accuracy through a "process of elimination". Lucy further revealed that she contextualised her findings within the broader historical landscape by initially thinking about "the legal connections" and cited the Matrimonial Clauses Act (1858) and Lord Hardwicke's Act (1753), and of the methods she used to break through 'brick walls'.

Antithetically to other case studies in this paper, Lucy's family history research did not function to create an affective relationship to her family past. She claimed her research has not impacted on her life, and she explicitly told of an impassive emotional connection to her ancestral past, despite her interest. She explained that "I could say I don't get horrified when I read things. Like you know in those Who Do You Think You Are? programmes you find the celebrities crying over small things about what their ancestor's gone through? I 
don't get emotionally attached like that". She explained that temporal distance, defined as "a position of detached observation made possible by the passage of time" (Phillips 2011, p. 11) was the reason why she could not connect with her ancestors by stating "I try to take an objective view towards what I look at because there is a distance between us. I don't feel completely connected with them, but I'm interested in finding out about them".

Lucy's research, however, did function to provide her with knowledge of the past and connect her to an estranged part of her family. She explained that "my parents divorced when I was very young, so I didn't have much contact with my Dad's family ... and it was really trying to bridge that gap". Another function of her research was to provide explanation as a means of understanding the perspectives of the people of the past, and to help to make sense of and explain their actions in both the past and the present. She revealed "And he was from a very poor Irish family and he used to walk to school barefoot and so it sort of gives you an impression of why he might have become a hardened person, because of his upbringing and the way he was treated".

Lucy's theories of history were well-defined, and her historical consciousness is best described in Rüsen's Typology as genetic. Lucy understands the constructed nature of history and spoke of the invisibility of women in older historical accounts and argued "it does disappoint me when I can't find out anything about some of my female convicts, because they're as much of my history as the men". She theorised history as a pedagogical tool in which the past "helps us reflect on what we should be doing in the present or the future to see what might have worked or might not have worked in the past, and how that might have influenced now, or what we should do in the future. It's a reflective exercise and you like to see what people in the past did, or events that happened in the past and how that's shaped us". Again, this reasoning is evidence of Lucy's high-level historical consciousness, as the past is used to understanding the present and considers its impact on the future.

- Case study 4: Claire (pseudonym), 68 year-old teacher

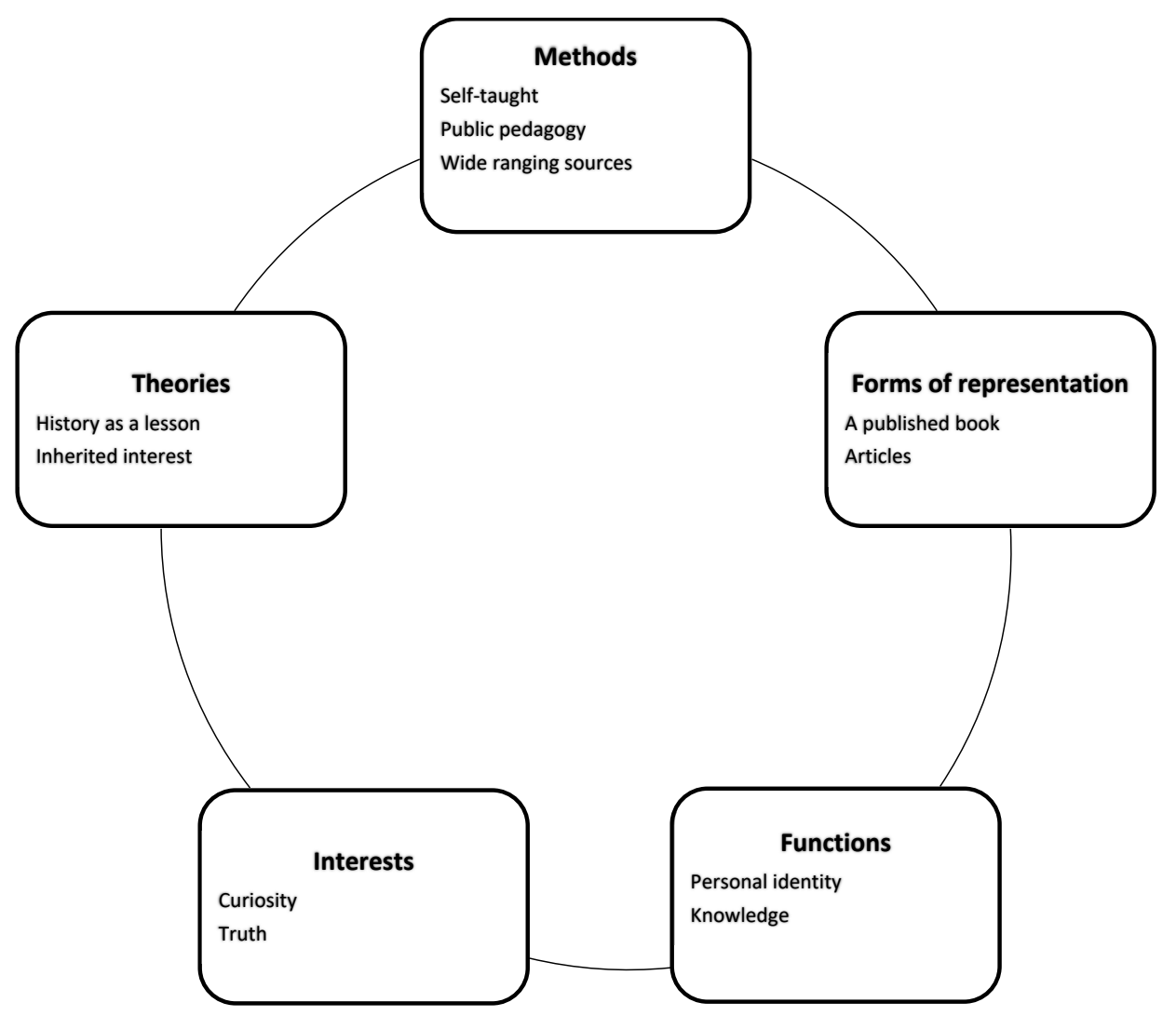

Figure 5. Case study four in alignment with Rüsen's (1993) Disciplinary Matrix. 
Claire is from Queensland, Australia. She identifies as Australian, with European ethnic and/or cultural background. She is highly educated having completed a coursework Masters degree, and is a science teacher in a secondary high school where she is Head of her Department. Claire is a very experienced family history researcher having commenced her familial research in 1984 and dedicates a maximum of $20 \mathrm{~h}$ per week on her family history research.

Claire is interested in history in many forms and is prompted by curiosity and a search for "truth." She views historical movies and documentaries on television, and she reads historical non-fiction books. "I'm one of those people who doesn't read fiction, so it's either history or autobiographies, or science books or something". Claire participated at a local historical society and explained that she was motivated by her research quest. "I just go out there if I wanna do research". She had not taken on special offices or duties within the society, but expressed an interest in doing so when she retires. As to forms of representation of her work, Claire wrote two articles for the society that had been published in their newsletter. Her methods of historical research are mainly self-taught. In the beginning, her research journey was ad hoc in its approach, and when interviewed and asked how she learned to 'do' her research, she stated:

It was a bit hard when I started ... because there was nothing online, there was no such thing as the internet. I used to go out to the Mormons, and they were very helpful, and I was using German records a lot, and they would get the film in and I'd sit there and read it painstakingly. Oh, and we used to go to the archives ... it was very, very time consuming."

Over the years Claire has developed advanced research skills in virtual and real contexts and has acquired the skills to locate, select, apply, and corroborate various and diverse historical sources.

I try to build up a picture of the person's life and see how it fits together, and usually you can find where the discrepancy is. You've gotta look at them in context, and you've gotta look at the bigger picture ... you can't sometimes just go to what you're tryin' to find out ... if it doesn't fit in, then it's not right is it?

An interesting revelation to emerge in the interview was that Claire had travelled internationally to Germany and Scotland to conduct her family history research. The literature refers to this as genealogical tourism (Santos and Yan 2009). With regard to Scotland, Claire talked of how her ancestors were cleared from the Highlands and "they were told to become fishermen, and it's such ... we visited up there and it's such barren sort of awful country, it'd be very hard to exist". In Scotland, she visited the village from which her ancestors came, and saw the house where they lived, which was, in her words, "quite thrilling". In Germany, Claire took many of the photographs featured in her book and it was this German family that was the basis of her book-another form of representation which had some modest success commercially.

When asked about her theories of history, Claire defined history as "events that are past-usually long past". Probed further in the interview about her interest in history more generally, she replied that "I think you can learn a lot from it really". Locating her interest in history to a familial trait, she mused that "I s'pose my mother was always interested in history, I might get it from her. I just think you learn a lot from history, and it helps you understand the world around you a lot better". As an example, she divulged that she had just finished reading a book about New Guinea during the Second World War. Her reason for doing so was an attempt to understand and contextualise her father's wartime experience as he was stationed there during the war. She told of how he always hated the Japanese, and "he went to his grave hating them".

When asked about her theories of history, Claire acknowledged that her family history research allowed her to see the importance of contextualisation:

I don't think you can research people without looking at the history behind it ... because it affects them so much, doesn't it? Everyday life and what they did and 
why they did it ... that's probably why I got interested in history, trying to put them into context.

Claire's contextualisation of her ancestors into their wider political and social milieus served an important function in her understanding of herself as an historical being. She located her ancestors in place and time, and sought to comprehend the actions and motives of people of the past through exploring the social/political/economic elements of the time period being researched. This process augmented her historical understanding and has led Claire to a greater understanding of her own life, and who she is as a person. While not being formally schooled in the conceptual underpinnings of the history discipline, Claire reveals a sophisticated approach to her research and a well-developed historical consciousness which can be aligned to genetic in Rüsen's Typology.

\section{Conclusions}

Each of the examined case study subjects is unique in their very different contexts backgrounds, ages and professions. However, the subjects in this study were all skilled at locating, corroborating, and contextualising historical sources to compile and disseminate historical accounts. The case study subjects were historically minded individuals who devoted considerable time to their family history research activities. All were enthusiastic about their research which attests to the strong personal connection that develops between the family history researcher and their ancestors. Through a process of trial and error, they had developed agile approaches to overcoming research obstacles. They used a variety of research apparatus shifting between archival and digital platforms and had established reciprocal connections with family history communities. With the exception of Jane, all learned their family history research skills in a public setting, with little tutoring from formalised institutions of learning. While they reported different motives for commencing their family history research, Lucy, Claire, and John were inspired by their family members' interest in the past. Lucy was inspired to continue her grandfather's research while John was motivated to investigate his family connection to a well-known colonial painting to confirm his mother's familial narrative. Claire saw her interest in history as a family trait which was passed to her from her mother. Jane's interest grew from her early encounters with history at school.

Through enacting historical research processes to develop narratives, they learned of the importance of contextualisation of historical accounts, and were shown to have a sophisticated historical consciousness. As shown in Jane's concluding statement, "For me, history is important. My research has helped me see its impact on modern life". They claim that this changed the ways they thought about the past, increased their historically related activities, and enhanced their understanding of the disciplinary nuances. Jane and Lucy were aware of current trend in historiographic discourses which sees a focus on previously marginalised voices. Claire travelled widely to confirm the stories of her family past and contextualised these to produce a published book. Lucy, Jane, and Claire's understanding of contextualisation and varying perspectives, which aligns with a genetic historical consciousness. John's research was less concerned with contextualisation but allowed him to critique and rewrite an established historical account and become an acknowledged authority in his field of investigation. His historical consciousness was categorised as critical as he sought to test and challenge accepted historical narratives.

This study asserts that family histories can be important contributors to public history, and that some family history researchers can be considered historians, despite being predominantly self-taught in historical research methodologies. All the case study subjects produced historical accounts of their research findings which took forms of family trees, journal articles, and monographs. With the exception of Lucy, these works have been disseminated for public consumption and education.

These case studies illustrate that family history research can become an agent for the evolution of an historical consciousness as theorised by Rüsen's Disciplinary Matrix and evidenced by his typology. By undertaking their research quests these individuals' 
relationships with the past can be seen to be enhanced through investigation and discovery. The ancestors and narratives they uncovered became part of their family story, as opposed to being distant historical happenings peopled by strangers. All four case study subjects reported their family history research gave them insight into historical research and writing and changed their sense of self. Learning about their families' past, the experiences of their ancestors, and contextualising these in a broader historical setting impacted on their identities, their pastimes, and their historical understanding. This research found that the historical consciousness of all the case study subjects was substantially augmented by their family history research.

Author Contributions: Conceptualization, E.L.S.; methodology, D.J.D.; formal analysis, E.L.S. and D.J.D.; investigation, E.L.S.; writing-original draft preparation, E.L.S. and D.J.D.; writing-review and editing, D.J.D. and E.L.S.; All authors have read and agreed to the published version of the manuscript.

Funding: This research received no external funding.

Institutional Review Board Statement: This project has been approved by the University's Human Research Ethics Committee, Approval No. H-2014-0353.

Informed Consent Statement: Informed consent was obtained from all subjects involved in the study.

Data Availability Statement: Not applicable.

Conflicts of Interest: The authors declare no conflict of interest.

\section{References}

Chapman, Arthur. 2014. "But it might not just be their political views": Using Jorn Rusen's Disciplinary Matrix to develop understandings of historical interpretation. Caderno de Pesquisa: Pensamento Educational 9: 67-85.

Creswell, John. 2012. Educational Research. Boston: Pearson.

Denzin, Norman. 2005. Emancipatory discourses and the ethics and politics of interpretation. In Handbook of Qualitative Research. Edited by Norman Denzin and Yvonna Lincoln. Thousand Oaks: Sage.

Donnelly, Debra, and Emma Shaw. 2020. Docudrama as histotainment: Repackaging family history in the digital age. Public History Review 27: 48-68. [CrossRef]

Evans, Tanya. 2021. Family history: Community and collaboration. In Family History and Historians in Australia and New Zealand. Edited by Malcolm Allbrook and Sophie Scott-Brown. New York: Routledge, pp. 197-207.

Freishtat, Richard, and Jennfier Sandlin. 2010. Shaping youth discourse about technology: Technological colonization, manifest destiny, and the frontier myth in Facebook's public pedagogy. Educational Studies: A Journal of the American Educational Studies Association 46: 503-23. [CrossRef]

Gadamer, Hans-Georg. 1977. The universality of the hermeneutical problem. In Philosophical Hermeneutics. Translated by David Linge. Los Angeles: University of California Press.

Gosselin, Viviane. 2012. Open to Interpretation: Mobilizing Historical Thinking in the Museum. Unpublished doctoral dissertation, University of British Columbia, Vancouver, BC, Canada.

Kramer, Anne-Marie. 2011. Kinship, affinity and connectedness: Exploring the role of genealogy in personal lives. Sociology 45: 379-45. [CrossRef]

Lee, Peter. 2004. 'Walking backwards into tomorrow'. Historical consciousness and understanding history. International Journal of Historical Learning, Teaching and Research 4: 67-106. [CrossRef]

Lincoln, Yvonna, and Egon Guba. 2000. The only generalization is: There is no generalization. In Case Study Method. Edited by Roger Gomm, Martyn Hammersley and Peter Foster. London: Sage.

Megill, Allan. 1994. Jorn Rusen's theory of historiography between modernism and rhetoric inquiry. History and Theory 33: 39-60. [CrossRef]

Merriam, Sharan. 1998. Qualitative Research and Case Study Applications in Education. San Francisco: Jossey-Bass.

Phillips, Mark. 2011. Rethinking historical distance: From doctrine to heuristic. History and Theory 50: 11-23. [CrossRef]

Rüsen, Jorn. 1993. The development of narrative competence in historical learning: An ontogenetic hypothesis concerning moral consciousness. In Studies in Metahistory. Edited by Jorn Rüsen. Pretoria: Human Sciences Council.

Rüsen, Jorn. 1996. Some theoretical approaches to intercultural comparative historiography. History and Theory 35: 5-22. [CrossRef]

Rüsen, Jorn. 2004. Historical consciousness: Narrative structure, moral function, and ontogenetic development. In Theorizing Historical Consciousness. Edited by Peter Seixas. Toronto: University of Toronto Press, pp. 63-85.

Rüsen, Jorn. 2006. Preface to the series. In Narration, Identity and Historical Consciousness. Edited by Jürgen Straub. New York: Berghahn Books. 
Sandelowski, Margarete. 1995. Focus on qualitative methods, sample size in qualitative research. Research in Nursing and Health 18: 179-83. [CrossRef] [PubMed]

Santos, Carla, and Grace Yan. 2009. Genealogical tourism: A phenomenological examination. Journal of Travel Research 49: 56-67. [CrossRef]

Seixas, Peter. 2006. What is historical consciousness? In To the Past: History Education, Public Memory, and Citizenship in Canada. Edited by Ruth Sandwell. Toronto: Toronto University Press, pp. 11-22.

Shaw, Emma. 2020. "Who we are and why we do it": A demographic overview and the cited motivations of Australia's family historians. Journal of Family History 45: 109-24. [CrossRef]

Stake, Robert. 1995. The Art of Case Study Research. Los Angeles: Sage.

Tellis, Winston. 1997. Introduction to Case Study. The Qualitative Report. Available online: http://citeseerx.ist.psu.edu/viewdoc/ download?doi=10.1.1.604.599\&rep=rep1\&type=pdf (accessed on 26 September 2021).

Thorpe, Robert. 2014. Towards an epistemological theory of historical consciousness. Historical Encounters 1: 17-28.

Yin, Robert. 1989. Case Study Research: Design and Methods. Thousand Oaks: Sage Publications. 